\title{
Current trends in the global tourism industry: evidence from the United States*
}

Nejdet Delener, PhD**

Summary: 1. Introduction; 2. The U.S. tourism industry: benefits; 3 . The U.S. tourism industry: market analysis; 4 . Current trends in the global tourism industry; 5. Stimulating the tourism industry: strategic recommendations.

Sumário: 1. Introdução; 2. A indústria do turismo dos EUA: benefícios; 3. A indústria do turismo dos EUA: análise do mercado; 4. As tendências atuais na indústria do turismo mundial; 5. Estimular a indústria do turismo: recomendações estratégicas.

KEY WORDs: travel and tourism industry; destination management; travel behavior.

Palavras-chave: indústria de viagens e turismo; gestão dos destinos turísticos; comportamento em viagem.

Tourism is one of the largest U.S. industries, serving millions of international and domestic tourists yearly. Tourists visit the U.S. to see natural wonders, cities, historic landmarks, and entertainment venues. Americans seek similar attractions as well as recreation and vacation areas. Tourism competes in the global market, so it is important to understand current trends in the U.S. travel industry. Therefore, this article offers insight into important trends and suggests strategies for policy makers involved in the travel and tourism industry

Tendências atuais da indústria de turismo global: aspectos dos EUA O turismo é uma das maiores indústrias dos EUA, que serve milhões de turistas domésticos e internacionais por ano. Eles visitam os EUA para ver as maravilhas naturais, cidades, monumentos históricos e locais de entretenimento. Os americanos

\footnotetext{
* Article received in May e accepted in Aug. 2010.

** President of The Global Business and Technology Association; editor-in-chief for the Journal of Global Business and Technology. Professor and Dean of the School of Business at the State University of New York. Address: 223 Store Hill Road — Old Westbury - 11568, Long Island, NY, USA. E-mail: delenern@oldwestbury.edu; delener@gbata.org.
} 
buscam atrações similares, bem como áreas de lazer e férias. O turismo compete no mercado global, por isso é importante entender as tendências atuais na indústria de viagens dos EUA. Portanto, este artigo oferece uma visão sobre as tendências importantes e sugere estratégias para os políticos tomadores de decisão envolvidos na indústria de viagens e turismo.

\section{Introduction}

"Life is a journey." How often have we heard that phrase or used it ourselves? It has been noted that it is humankind's most appropriate metaphor. The notion of travel is hard-wired into the human experience. In ancient times, travel was motivated by the desire for exploration, discovery, and enrichment, and times have not changed much. A longing to explore, to discover, and to become enriched still drives people to travel today. The desire to travel has made travel and tourism the number one industry in many countries of the world and the largest service sector for the United States. The travel and tourism industry is one of the few industries credited with producing a positive trade balance for the U.S. economy. It is one of the largest employers, developing workers at all levels and areas of expertise.

According to the Travel Industry Association (TIA), tourism accounts for $\$ 740$ billion in direct travel expenditures by both domestic and international travelers. International travelers to the United States spend $\$ 107.9$ billion every year. Outside the U.S., Americans spend $\$ 99.6$ billion on tourism, creating an $\$ 8.3$ billion U.S. trade surplus in the sector. Tourism provides $\$ 110$ billion in tax revenue for federal, state, and local governments. In terms of direct spending by residents and international travelers, the TIA estimates $\$ 2$ billion per day is spent in the U.S. on travel-related items. The average overseas visitor to the U.S. spends $\$ 1,647$, with average trip duration of five to six nights. Additionally, the tourism industry is one of America's largest employers, providing $\$ 7.9$ million jobs and spending $\$ 178$ billion in direct travel-related payroll (The Travel Industry Association (TIA), Facts and Information). But the travel and tourism industry is exceedingly complex. In fact, it has been called the "industry of industries," in recognition of the fact that travel-related firms range in size from multinational enterprises operating out of high-rise towers to individuals selling travel products and services from their homes. Furthermore, the tourism industry still faces the challenge of cautious consumers due to current economic, social, and political realities. Tourism competes in a global market, and it is important to understand the current trends in 
the industry. Therefore, the objectives of this paper are: to offer insight into important trends in the U. S. travel and tourism industry; to analyze developments in destination management and general travel behavior; and to suggest strategic recommendations for managers and policy makers involved in travel and tourism.

\section{The U.S. tourism industry: benefits}

The benefits of the U.S. tourism industry go beyond the value provided to foreign travelers. The tourism industry produces the following benefits.

It stimulates the economy. In 2009, foreign travelers spent about $\$ 100$ billion in the United States. Foreign tourists often spend three times that of domestic travelers - an extraordinary investment in the U.S. economy. While the tourism industry has suffered in today's rough economic climate, additional taxes, such as the one proposed under the Travel Promotion Act, threaten to exacerbate the challenges faced by the industry. The Travel Promotion Act of 2009 imposes a $\$ 10$ fee on visitors coming from visa waiver countries. The money would be used to create marketing campaigns to help bring visitors to the United States. However, the more visitors spend in taxes, the less they have to spend in the United States on everything from hotels to cabs and souvenirs.

It promotes America's image abroad. When foreign travelers come to America, interact with Americans, and gain an understanding of what makes America great, they share these positive experiences with members of their own society, helping to improve America's image.

It keeps Americans safer. Programs like the Visa Waiver Program (VWP) - which allows visitors from member countries to come to the United States for up to 90 days without a visa - bring more tourism dollars into the United States. But VWP also makes America safer by ensuring that the U.S. knows more about foreign visitors before they reach U.S. soil. Furthermore, the information-sharing agreements that go along with country membership in the VWP help the U.S. stop acts of terrorism, and preventing acts of terrorism further preserves tourism.

\section{The U.S. tourism industry: market analysis}

Inbound market: The United States welcomed 56 million visitors from 213 countries last year, an increase of about $10 \%$ from the previous year. Total 
arrivals were also up approximately $9 \%$ from 2000, the former record year for total non-resident visitation to the country. Arrival records were set by 72 countries, nine of which were among the top 10 inbound markets (Otti, U.S. Travel \& Tourism Statistics Inbound). Therefore, last year, the growth in arrivals was driven more from the emerging markets than the top arrival markets. For adventure companies with U.S. itineraries, this trend signals a need to begin shifting some marketing efforts to new and emerging destinations.

Canada and Mexico still account for a majority of the visitors to the United States for a total of $58 \%$ of all arrivals last year. Europe is second at $20.6 \%$, with a growth in numbers of about $13 \%$ before the last two years. However, other regions experienced rapid growth, with South America contributing $18 \%$ more visitors during the last year than in the previous year.

The top 20 inbound visitor markets accounted for $74 \%$ of all international arrivals to the U.S. last year, and as a group, were up $11 \%$ compared to previous years. The top 10 countries that sent the most visitors to the U.S. are: 1. Canada; 2. Mexico; 3. The United Kingdom; 4. Japan; 5. Germany; 6. France; 7. South Korea; 8. Australia; 9. Brazil; and 10. Italy.

Outbound market: The overall United States outbound market grew by $1 \%$ last year to a total of 64 million U.S. residents traveling abroad, enabling it to post the fourth successive record for total U.S. outbound travel. This growth came entirely in travel to overseas regions, excluding Canada and Mexico, which experienced declines of one percent and three percent respectively (Otti, U.S. Travel \& Tourism Statistics Outbound).

While Canada, Mexico, and Europe are still the dominant destinations of choice for Americans, other regions of interest are growing rapidly, most particularly Central America and Africa, followed by the Middle East and South America. U.S. travelers continue to originate primarily in the following three regions: the Middle Atlantic, Pacific, and South Atlantic. For adventure travel companies, knowledge of where in the U.S. international travelers reside is useful when developing marketing strategies.

Despite a fairly optimistic picture compared with last year, in the last two decades, the U.S. has lost tourism market share for inbound travel. In addition, outbound travel continues to lag when compared to other nations, most particularly those in Europe. Alarmed by this deteriorating situation, the U.S. travel and tourism advisory released a report recommending a nationallycoordinated marketing and advertising campaign that communicates the common qualities of U.S. destinations to stimulate growth in the tourism industry. While some individual destinations and private sector businesses from the U.S. currently invest in marketing internationally, the author of the report believes 
that the absence of a nationally coordinated umbrella campaign represents a significant competitive disadvantage for the U.S.

\section{Current trends in the global tourism industry}

In response to current economic, social, and political realities, the current trends in the travel and tourism industry are:

\section{Continued growth: 4-5\% growth in the worldwide travel industry; $1-2 \%$ growth in U.S. tourism}

By the year 2020, tourism will be the world's largest industry. Travel and tourism is the third largest retail industry in the U.S. behind automotive dealers and food stores. The World Travel and Tourism Council estimates that in 2007 the tourism industry accounted for approximately $10 \%$ of the total worldwide GDP and employed 230 million people. Further, the industry is estimated to generate approximately $\$ 5$ trillion in worldwide economic activity, with approximately $\$ 700$ billion of that taking place in the U.S. Worldwide, the travel industry is expected to grow at about a 5\% rate annually over the foreseeable future (Travel and Tourism Works for America, September 2006, Travel Industry Association). The Travel Industry Association of America (TIA) projects 2007 revenues at $\$ 739.4$ billion and forecasts 2008 revenues at $\$ 775.9$ billion. The revenues for 2009 are forecast at $\$ 806.2$ billion. However, there has been a significant change in the industry since 2000 , with various sectors of the industry struggling and adjusting to the future marketplace. Americans took 1,254.6 million domestic-person trips in 2007, a 2.3\% increase over the previous year (Otti, 2009 Monthly Tourism Statistics).

\section{Time poverty $=$ more to do + less time to do it - affects every travel segment}

Americans suffer from "time poverty" - the generalized sense that people do not have enough time to do what they want. Americans work an average of nine full weeks (350 hours) more per year than their European counterparts (see table 1). $80 \%$ of men and $62 \%$ of women put in more than 40 hours a week on the job. Americans work longer hours than medieval peasants did. 
According to a national survey by the University of Michigan's Survey Research Center, nearly one in five workers now spends more than 50 hours per week at work. Since the late 1970s, children have lost 12 hours per week in free time, including a $25 \%$ drop in play overall and a 50\% drop in unstructured outdoor activities. The Survey Research Center also found that students spend eight hours more a week in school than kids did 20 years ago, and homework time has nearly doubled.

Unlike 127 other countries, the U.S. has no minimum paid-leave law. Australians have four weeks off by law, the Europeans four and five weeks, the Japanese two weeks. The U.S. has zero. Expedia research shows that Americans, with an average of 12 vacation days per year, leave a total of 421 million vacation days unused. Nearly $1 / 3$ of respondents to Expedia's 2005 survey reported that they did not take all their vacation days.

\section{Table 1}

Average number of vacation days

\begin{tabular}{|cl|}
\hline Italy & 42 days \\
France & 37 days \\
Germany & 35 days \\
Brazil & 34 days \\
United Kingdom & 28 days \\
Canada & 26 days \\
Korea & 25 days \\
Japan & 25 days \\
U.S. & 13 days \\
\hline
\end{tabular}

Source: Adapted from UNWTO.

Since people have less free time, there is greater competition for those rare leisure hours. For instance, museums and attractions continue to expand and multiply while attendance is shrinking. Cruise lines continue expanding with new and larger cruises to far-reaching exotic ports. All this results in more to do and less time in which to do it. This is one of the top trends underlying the travel and tourism industry.

\section{Fragile consumer confidence affecting travel decisions}

Consumers' assessment of present-day conditions continues to grow more negative, suggesting that the economy remains stuck in low gear. Looking ahe- 
ad, consumers' economic outlook is so bleak that the Expectation Index has reached a new all-time low. Perhaps the silver lining to this otherwise dismal report is that Consumer Confidence may be nearing a bottom (www.conference-board.org). The Conference Board Consumer Confidence Index for June 2008 now stands at $50.4(1985=100)$, down from 58.1 in May. The record highest level was 144.7 achieved in 2000.

\section{Soaring fuel costs affecting every aspect of travel - an enormous challenge for the travel industry}

The skyrocketing price of fuel could "devastate" the airline industry and hurt the economy. The failure of just one airline could disrupt travel for 200,000 to 300,000 daily passengers and cause between 30,000 and 75,000 immediate job losses (TIA Facts and Information).

By the summer of 2010 , there could be $20 \%$ fewer seats as air carriers cut flights to meet lower operating overheads. Small and mid-size cities now served mainly by 50 -seat regional jets might see dramatic cuts resulting in challenges for recruiting conventions, new factories, and corporate offices. From one-on-one interactions with AAA members, 95\% of AAA auto travel managers say high gas prices will cause travelers to alter their summer vacation plans. Managers cited travelers taking trips closer to home, taking fewer trips, and reducing the number of vacation days traveled as the top ways that Americans are adjusting their travel plans. Cruise lines are adding fuel surcharges of $\$ 5-\$ 12$ per day per passenger and scrambling to reduce their fuel use.

\section{Continued growth of traveler frustration - high costs \& poor service results in loss}

Frustrations with the airline industry spurred air travelers to avoid 41 million trips last year according to a report by the Travel Industry Association (TIA). The research, conducted by polling firms Peter D. Hart Research Associates and The Winston Group, placed this trip avoidance cost at $\$ 26$ billion. Additionally, the TIA reports that more than $60 \%$ of respondents believe the air travel system is deteriorating, and more than $50 \%$ do not expect the air travel system to improve in the near future. Airline delays, cancellations and inefficient security screenings were the aspects of flight that travelers found most 
irritating. The TIA also points to the wider implications of this kind of trip avoidance: besides the $\$ 9$ billion in revenue lost by the airlines, hotels reportedly lost nearly $\$ 6$ billion and restaurants more than $\$ 3$ billion. The $\$ 26$ billion also includes $\$ 4$ billion that federal, state and local governments lost in tax revenue due to the spending decrease by travelers.

The U.S. airline industry received the worst score ever recorded in the most recent Airline Quality Rating (AQR) study. In the same study, consumer complaints were up $60 \%$ over last year. According to the American Customer Satisfaction Index, the hotel business has received its lowest industry-wide rating since 2002. "Staycations" are another way travelers are voicing their frustration. It has become more desirable just to stay home.

\section{Internet: \# 1 source of travel planning and purchasing - however, the consumer is becoming the medium for travel information via "social media" and networking sites}

The Conference Board and TNS surveys 10,000 households nationwide in an annual Consumer Internet Barometer survey of internet usage. According to their data, consumers conducting travel research (planning) outnumber those booking online two-to-one. Also, one out of every four people online visits social networking sites such as TripAdvisor.com for travel information (www. conference-board.org).

According to the YPartnership's 2008 Travel Monitor Study, one out of five travelers have used a "blog" to read a review about a travel service provider. Also, while use of the internet has stabilized, the number of consumers buying online travel is still growing. RTM predicts this consumer-to-consumer style of travel information sourcing will be one of the largest trends to affect the travel and tourism industry in the near future. Simply put, the consumer is now in control of tourism marketing. Forrester Research predicts that travel will remain the number one online retail category and grow to $\$ 119$ billion by 2010 (Hotelmarketing.com).

The majority of leisure travelers who are airline and hotel users (66\%) now go exclusively to the internet when planning a vacation, while $57 \%$ report making reservations online. These numbers underscore the remarkable way in which consumers have embraced this medium since 2000, at which time only $35 \%$ of leisure travelers used the Internet to plan travel and just 19\% actually made a reservation online (YPartnership 2007 National Leisure Travel Monitor ${ }^{\mathrm{TM}}$ ). 


\section{Business travel: Slight growth and vigilant cost containment}

The growth of business travel will be slower. Businesses have cut back on travel and instead rely on less expensive communications capabilities such as webcasts and videoconferences. According to the 2008 American Express Global Business Travel Forecast, an average business trip (including airfare, car rental, and hotel stay) will hit $\$ 1,110$ in $2008,6 \%$ more than 2007 . International trips will increase by $7 \%$ to $\$ 3,171$.

\section{Geotourism}

Geotourism, an emerging sector in tourism, is defined as tourism that sustains or enhances the geographical character of a place being visited - its environment, culture, and heritage. American travelers are choosing more rural and out-of-the-way destinations, focusing in part on cultural, historic and natural resources. According to a study conducted by the Travel Industry Association of America (TIA) and National Geographic Traveler, 55.1 million Americans are considered geotourists. The report divides geotourists into three segments: Geo-savvies (16.3 million), Urban sophisticates (21.2 million), and baby boomers show a distinct preference for culturally and socially related travel. They share an intellectual curiosity as reflected in their well-above average tendencies to participate in a number of educationally-and culturally-oriented activities in their local communities. They also share more highly developed social consciences, engaging in pro-environment behaviors at home and more actively supporting environmental and cultural organizations through donations of time and money than the other segments.

\section{Generational shifts}

Silent generation/matures: The aging population is not just a U.S. phenomenon. By 2020, there will be 700 million people over age 65 worldwide (Deloitte $\&$ Touche, 2009). Matures travel but limit spending, looking for value and freebies. Baby boomers are entering their sixties. Travel tops the list of desired retirement activities as retirees seek luxury, fulfillment, bragging rights, and comfort.

Generation $X$ is becoming a driving force in multigenerational travel and is also entering peak earning years. 
Generation $Y$ ("slaves to the screen") tends to stay at home, preferring to spend on electronics. However, a growing and more diverse student population is traveling at higher rates and at earlier ages, taking more expensive trips, using technology, demanding more from their travel experience, and selecting destinations further away than those of previous generations.

The $M$ generation - the " $\mathrm{M}$ " stands for multitasking and mobile - is the generation that has grown up with the iPod, text messaging on their cell phones, and other forms of continuous and instant communication. The M Generation demands reinvented travel.

\section{More demand by all travel segments for orientation and facilitation}

Time poverty underpins this trend. Regardless of the type of traveler (business, leisure, meeting, etc.), today's traveler is impatient with the process of "finding the good stuff." From preferred restaurants, to lodging, to things to see and do, travelers report frustration with having to dig through tons of brochures, websites, etc. to find travel choices. They want someone or something that gives them instant and easy information. Online concierge services such as travelnewyork.com are proliferating as consumers seek easier trip planning where planning services are provided.

\section{Other trends}

Disaster \& crisis planning: Terrorism, weather, natural disasters, Avian Flu etc.

The travel industry has learned hard lessons recently about the need to prepare for disasters, including terrorist attacks, earthquakes, tsunamis, hurricanes, wild fires, SARS and the Avian Flu. Airlines, airports, hotels, theme parks, and cruise lines are all working to be prepared for the next disaster. DMOs are now advised to maintain 3-6 months of operating revenues in case of disaster.

\section{Family reunion travel}

According to the Gale Group, there are more than 200,000 family reunions in the U.S. each year, attended by 8 million people. Reunions Magazine reports $73 \%$ of reunions have 50 or more attendees, and 35\% have more than 100 . 
$6 \%$ have more than 200 attendees. 85\% of reunions occur in June, July, and August. $64 \%$ of families expect to use a hotel or resort for their next reunion (Reunions Magazine, 2009).

\section{Youth sports travel}

Parents who travel to attend games represent a growing sub-segment of the sports travel segment. According to the TIA, more than 52 million Americans attended an organized sports event, competition, or tournament as either a spectator or participant while traveling.

\section{International travel}

A growth of $4.6 \%$ annually has been projected for each of the next ten years. There are a number of factors that will continue to strengthen international travel in general and travel to the United States in particular, helping reverse noticeable declines in arrivals from many major inbound markets from earlier years. First, strong economic growth in most regions - spurred by continued expansion in China, renewed signs of life in some of the Eurozone's core economies, and low interest rates around the world — will generate increases in business and leisure travel. Furthermore, the strong performance of a number of major currencies relative to the U.S. dollar has made travel to the United States more affordable for a large number of international travelers.

\section{Stimulating the tourism industry: Strategic recommendations}

The United States needs to work diligently to support sectors of the economy such as the tourism industry. First, the federal government should do the following:

v Leave tourism promotion to the private sector. Tourism promotion and advertising are private-sector functions. With decades of experience in the business, private-sector companies know the best methods for promoting tourism;

v Expand the Visa Waiver Program (VWP). The VWP is an excellent way to sustain the tourism industry, make Americans safer, and improve the U.S.'s 
image abroad. The Department of Homeland Security (DHS) and Congress should work together to ensure that the membership process continues;

- Target border infrastructure investments at ports of entry (POEs). Congress and DHS should address infrastructure deficiencies at POEs. POEs are dilapidated and inefficient. Wait times continue to dissuade people from coming to the United States. Investments in this infrastructure will support tourism by making travel between the U.S. and other nations more efficient;

- Improve visa services. Congress should move forward on visa reform so that employers can legitimately get the workers they need to grow the economy. These same employees are likely to be tourists while in the United States, using their time abroad to see America and taking a positive image back to their home countries.

Second, companies should target marketing efforts to reach travelers in regions of the U.S. where most U.S. international travelers are shown to originate such as the Middle Atlantic and Pacific regions. Additionally, multidestination companies should promote regions that are of growing interest to U.S. travelers as a way to build brand awareness and customer brand relationships. (For example, emphasizing trips to Central/South America and African destinations may have greater appeal for U.S. travelers.)

Third, U.S. companies should address the fears and concerns of international travelers. For U.S. companies serving international visitors, travelers originating in developing countries and emerging markets are of growing importance in a source market. Since many potential visitors may be worried, for example, that they will be detained for hours because of a simple misstatement at a U.S. airport, U.S. companies should address fears and concerns such as these when dealing with foreign agents and when developing market materials.

Fourth, governments should take steps to encourage private investment in the commercial space tourism industry as soon as possible. The formal Space Tourism Study Program underway within the Japanese Rocket Society since 1993 is widely accepted as a reasonable baseline for discussion of the potential for establishing a commercial space tourism industry. In the absence of serious disruption to world economic growth, by 2030, the space tourism industry could be carrying some 5-10 million passengers/year to low Earth orbit, with some 50,000-100,000 guests staying simultaneously in a range of accommodation facilities in orbit, including hostels, hotels, resort hotels, and sport centers. Tourism services to hotels orbiting the moon and the lunar sur- 
face can also be expected to be underway based on technical capabilities that are already more than decades old.

\section{References}

DELOITTE \& TOUCHE. 2009.

GALLUP.COM. Available at: <www.gallup.com/poll124889/tourism-industry>. GLOBAL INSIGHT, INC. US travel outlook dims. June 25, 2008.

NATIONAL ASSEMBLY OF STATE ARTS AGENCIES. Available at: <www.nasaaarts.org/artworks/profile.shtml>.

OTTI. 2009 Monthly tourism statistics. Available at: <www.hotelmarketing. com>.

. US travel \& tourism statistics inbound. Available at: < tinet.ita.doc.gov/outreachpages/inbound.generalinformation.inbound_overview.html>.

. US travel \& tourism statistics outbound. Available at: < tinet.ita.doc.gov/outreachpages/inbound.generalinformation.outbound_overview.html>.

RANDAL TRAVEL MARKETS. Available at: <RVTravel.com.RVTA>.

REUNIONS MAGAZINE. 2009.

SYTA (Student Youth Travel Association).

TIA (Travel Industry Association). International travel to the U.S. Available at: < tia. org/researchpubs/itnl_tourism_travel_us $>$.

. Facts and information. Available at: < poweroftravel.org/statistics/>.

.Economic research: Economic impact of travel and tourism. Travel statistics and trends. Available at: < tia.org/travel/econimpact.asp > .

. Travel and tourism works for America. Available at: < tia.org/researchpubs/ itnl_tourism_travel_us.html >.

. Travel and tourism works for America. Sept. 2006.

YPARTNERSHIP. National Leisure Travel Monitor ${ }^{\mathrm{TM}} .2007$. 